\title{
Um discurso e um método Abordagem pragmalinguística do texto de Jo 5,19-47 na perspectiva da unidade de sua comunicação
}

Orientadora: Maria de Lourdes Corrêa Lima

Doutoranda: Tânia Maria Couto Maia

Área de Concentração: Teologia Bíblica

Linha de Pesquisa: Análise e Interpretação de Textos do Antigo e Novo Testamento

Um discurso e um método. Abordagem pragmalinguística do texto de Jo 5,19-47 na perspectiva da unidade de sua comunicação. O presente trabalho tem como objetivo a compreensão do texto discursivo de Jo 5,19-47 como uma unidade temática a partir da perspectiva de sua comunicação. Constata-se que o texto de Jo 5,19-47 não tem recebido o tratamento requerido pelo texto no contexto do Evangelho. Esta constatação evidenciou a necessidade de se investigar o referido texto, em nova abordagem, a partir de sua situação comunicativa. A escolha de uma proposta metodológica de aproximação ao texto bíblico como literatura levou a tomar como instrumento de mediação o método da pragmalinguística. O discurso de 5,19-47 com sua afirmação da unidade de ação do Pai e do Filho, testemunhada por sua Palavra de vida eterna (v. 24), é de máxima importância para toda a teologia do Evangelho, não só por constituir-se numa unidade temática bem determinada, que oferece o substrato teológico que sustentará o desenvolvimento progressivo da doutrina da teologia da encarnação, mas também porque é o texto que, em larga escala, oferece ao leitor a chave da compreensão do mistério da filiação divina para sua confissão de fé em Jesus como "Messias e Filho de Deus" (20,31).

Palavras-chave: Pai - Filho; enviado; Palavra. 